\title{
Production and characterisation of monoclonal antibodies to heat-shock protein 60 of Helicobacter pylori
}

\author{
H. YAMAGUCHI, T. OSAKI*, H. TAGUCHI, T. HANAWA, T. YAMAMOTO and S. KAMIYA \\ Department of Microbiology and *Division of Flowcytometry, Kyorin University School of Medicine, Mitaka, \\ Tokyo 181, Japan
}

Two monoclonal antibodies (MAbs), designated as H9 (IgG2a) and H20 (IgM), directed against heat-shock protein 60 (HSP60) of Helicobacter pylori strain TK1029 were established. Affinity-purified antigens cross-reacted in immunoblots with MAb H9 and MAb $\mathrm{H} 20$ respectively. These antigens also reacted with the $3 \mathrm{C8} \mathrm{MAb}$ previously established in this laboratory, which recognised Yersinia enterocolitica HSP60. By aminoacid sequence analysis, the $\mathrm{N}$-terminal amino-acid sequence of the protein recognised by both $\mathrm{H} 9$ and $\mathrm{H} 20$ MAbs was confirmed as the amino-acid sequence of $\boldsymbol{H}$. pylori HSP60 reported previously. Both MAbs reacted with nine strains of $H$. pylori in enzyme-linked immunosorbent assay (ELISA) and immunoblot analysis. In addition, MAb $\mathrm{H} 9$ reacted with extracts of other bacteria including $H$. mustelae, Pseudomonas aeruginosa, Vibrio cholerae, Serratia marcescens, Proteus mirabilis, Escherichia coli and Shigella sonnei. In contrast, MAb $\mathrm{H} 20$ reacted only with strains $H$. pylori. These results suggest that both the species-specific epitope recognised by MAb H20 and the common epitope recognised by MAb $\mathrm{H9}$ exist on HSP60 of the bacterial cell. Both MAbs also reacted with the 60kDa protein in the lysate of human gastric carcinoma (MKN45) cells. It was shown by immunohistochemical staining that gastric epithelial cells of four out of six biopsy specimens examined stained positively with MAb H20. These results suggest that there is a common epitope in $H$. pylori HSP60 and human gastric epithelial cells.

\section{Introduction}

Helicobacter pylori is a gram-negative, spiral-shaped bacterium that colonises human gastric mucosa and is implicated in the causation of peptic ulcer disease, gastric carcinoma and gastric lymphoma [1-3]. Various virulence factors have been identified in $H$. pylori including flagella $[4,5]$, adhesin $[6]$, urease $[7,8]$, vacuolating toxin $[9,10]$ and the toxin that inhibits secretion of gastric acid in vitro $[11,12]$. However, the pathogenic mechanism by which $H$. pylori persists in the stomach is not fully understood.

Heat-shock proteins (HSPs) are highly conserved proteins found in all prokaryotic and eukaryotic cells, induced by environmental stress including temperature chain, inflammation, viral infection and malignant transformation [13-15]. The HSP60 family of chaper-

Received 4 Feb. 1997; revised version accepted 28 March 1997.

Corresponding author: Dr H. Yamaguchi. onins such as GroEL of Escherichia coli and the 65$\mathrm{kDa}$ immunodominant antigen of Mycobacterium spp. is thought to facilitate folding, unfolding and translocation of polypeptides, as well as the assembly and fragmentation of oligomeric protein complexes [1618]. $H$. pylori HSP60 has been reported to be associated with urease $[19,20]$. A recent study demonstrated a correlation between the adhesion of $H$. pylori to human gastric carcinoma cells and expression of HSP60 on the cell surface [21]. The results suggested that the adhesion of $H$. pylori to human gastric cells might be associated with the HSP60, and also indicated a potential role of HSP60 as one of the virulence factors responsible for the induction of gastritis. However, the immunological nature of $H$. pylori HSP60 is currently unknown.

On the other hand, several investigators reported that H. pylori induces autoantibodies that play a crucial role in the pathogenesis of gastritis and gastric atrophy $[22,23]$. Autoimmunity also might play a role in the pathogenesis of $H$. pylori-linked chronic gastritis and carcinoma [2, 3]. To understand the autoimmune 
response involved in induction of chronic gastritis and carcinoma by $H$. pylori, studies of epitope homology between HSP60 of $H$. pylori and human gastric epithelial cells must be important.

The present study established monoclonal antibodies (MAbs), designated as $\mathrm{H} 9$ and $\mathrm{H} 20$, directed against HSP60 of $H$. pylori and studied the immunological characteristics of epitopes of HSP60 with an enzymelinked immunosorbent assay (ELISA) and immunoblotting with the MAbs. It also investigated crossreactivities between $H$. pylori and human gastric cells with these MAbs.

\section{Materials and methods}

\section{Bacterial strains and culture conditions}

H. pylori TK strains used in this study were isolated from gastric biopsy samples of patients as described previously [24]. $H$. pylori NCTC11638 and $H$. mustelae NCTC12032 were kindly provided by Dr T. Ito (Tokyo Metropolitan Research Laboratory of Public Health). These bacteria were cultured in Brain Heart Infusion (BHI) agar (Difco Laboratories, Detroit, USA) with defibrinated horse blood (BHI-blood plate) $5 \%$ in an atmosphere consisting of $\mathrm{O}_{2} 5 \%, \mathrm{CO}_{2} 10 \%, \mathrm{~N}_{2} 85 \%$ for 4 days at $37^{\circ} \mathrm{C}$. Pseudomonas aeruginosa, Vibrio cholerae, Serratia marcescens, Proteus mirabilis, E. coli and Shigella sonnei were obtained from the strain collection of the Department of Microbiology, Kyorin University School of Medicine. Cultures were harvested and then washed with phosphate-buffered saline (PBS); $0.14 \mathrm{M} \mathrm{NaCl}$ in $20 \mathrm{mM}$ sodium phosphate buffer, $\mathrm{pH}$ 7.4). The cells were resuspended in PBS and treated with an ultrasonic disintegrator UR-200P (Tomy Seiko Co., Tokyo, Japan) for $1 \mathrm{~min}$ at $20 \mathrm{kHz}$. The sonicated antigens were used for the ELISA and SDS-PAGE.

\section{Cell culture}

The human gastric carcinoma (MKN45) cell line was obtained from the Japanese Cancer Research Resources Bank (JCRB). MKN45 cells were grown at $37^{\circ} \mathrm{C}$ in RPMI 640 (Gibco Laboratories, NY, USA) containing fetal calf serum (FCS; Wako Pure Chemical Ltd, Osaka, Japan) $10 \%$ in an atmosphere of air with $\mathrm{CO}_{2}$ $5 \%$. The cells were resuspended in PBS and ultrasonically disintegrated as described above. The sonicated cells were used for ELISA and SDS-PAGE.

\section{Preparation of monoclonal antibodies}

MAb was prepared by the method described previously [25]. The $60-\mathrm{kDa}$ antigen derived from $H$. pylori TK1029, partially purified by extraction from the separation gel by SDS-PAGE. BALB/c mice were immunised intraperitoneally (i.p.) with the antigen mixed with Freund's complete adjuvant (Difco Labora- tories), three times at intervals of 10 days. Ten days after the last i.p. injection, the mice were given the partially purified antigen by intravenous injection. Three days later the spleen was removed for cell fusion of spleen cells and mouse myeloma cells (P3X63-Ag8-U1). The hybridoma cells producing MAb which reacted with the partially purified antigen, purified HSP60 from Yersinia enterocolitica [26] and the sonicated MKN45 cells were collected. The hybridoma cells displaying apparent specific antibody production were cloned by limiting dilution and $10^{6}$ cells were inoculated i.p. into BALB/c mice pretreated i.p. with pristane (Wako Pure Chemical Co. Ltd) $0.5 \mathrm{ml}$ 4 days before injection of the cells. Approximately 2 weeks later, ascites fluids were obtained from each mouse. The immunoglobulins in the ascites fluids were purified with an Immunoglobulin-Easy-Separation kit (Pharmacia Biotech. Co., Tokyo, Japan). The purified MAbs were used for ELISA, immunoblotting, flow cytometric analysis, immunohistochemical staining and affinity purification of the antigen recognised by the MAbs.

\section{Microsequencing of protein}

To analyse the N-terminal protein sequence, the whole proteins of $H$. pylori TK1029 were separated by SDSPAGE and transferred onto Immobilon membranes (Millipore, Bedford, USA). The band corresponding to the protein which recognised the H9 and H20 MAbs was excised from the membrane. The membrane piece was sequenced by a protein sequencer (473A; Applied Biosystems, Foster City, USA).

\section{ELISA}

ELISA was performed as previously reported [27]; 96well microtitration plates were coated for $2 \mathrm{~h}$ with partially purified $60-\mathrm{kDa}$ antigen derived from $H$. pylori TK1029, Y. enterocolitica HSP60 and the sonicated antigens from MKN45 cells at a concentration of $1 \mu \mathrm{g} /$ well. After washing with PBS, the plates were incubated with skimmed milk (Yukijirushi Nyugyo Co., Tokyo, Japan) $1 \% \mathrm{w} / \mathrm{v}$ (PBS-S) for $1 \mathrm{~h}$ at room temperature. The plates were then incubated for $1 \mathrm{~h}$ at room temperature with MAbs $\mathrm{H} 9$ and $\mathrm{H} 20$, diluted to $1 \mu \mathrm{g} / \mathrm{ml}$ with PBS-S. After washing, the plates were incubated with goat anti-mouse $\operatorname{IgG}$ and IgM peroxidase conjugate (Capel Research Products, Durham, USA) diluted 1 in 500 with PBS-S. Then the plates were developed with OPD buffer $(0.1 \mathrm{M}$ citric acid, $0.07 \mathrm{M}$ sodium phosphate 12-hydrate and $\mathrm{H}_{2} \mathrm{O}_{2}$ $0.015 \% \mathrm{v} / \mathrm{v}$ containing $o$-phenylenediamine $0.1 \% \mathrm{w} / \mathrm{v}$. After $5 \mathrm{~min}$ for the reaction, the colour which developed was measured at $490 \mathrm{~nm}$.

\section{SDS-PAGE and immunoblotting}

SDS-PAGE was done with acrylamide $10 \% \mathrm{w} / \mathrm{v}$ as described by Laemmli [28]. Bacterial cells were 
harvested and resuspended in $100 \mu 1$ of the lysis buffer (0.4 mM 2-mercaptoethanol, Nonidet P-40 3.2\% v/v, lysed by seven freeze-thaw cycles (frozen at $-80^{\circ} \mathrm{C}$ and thawed at $37^{\circ} \mathrm{C}$ in a water-bath, each for $5 \mathrm{~min}$ ). Cell lysates $(100 \mu 1)$ were heated for $5 \mathrm{~min}$ at $100^{\circ} \mathrm{C}$ in sample buffer $(0.00625 \mathrm{M}$ Tris- $\mathrm{HCl}, \mathrm{pH} 6.8$, containing SDS $2 \% \mathrm{w} / \mathrm{v}$, glycerol $5 \% \mathrm{v} / \mathrm{v}$ and 2 -mercaptoethanol $5 \% \mathrm{v} / \mathrm{v}$. Finally, $10 \mu \mathrm{l}$ of the cell lysates were loaded per lane. Immunoblot analysis was as described by Towbin et al. [29]. After electrophoresis, the separated proteins were transferred to nitrocellulose membranes (Schleiher and Schuell, Dassel, Germany) at $0.25 \mathrm{~A}$ overnight. After blocking with gelatin $3 \% \mathrm{w} / \mathrm{v}$ in Tris-buffered saline $(0.15 \mathrm{M} \mathrm{NaCl}, 10 \mathrm{mM}$ Tris- $\mathrm{HCl}$, $\mathrm{pH}$ 7.4), the membranes were treated for $1 \mathrm{~h}$ with $\mathrm{MAb} \mathrm{H} 9$ or MAb $\mathrm{H} 20$ diluted to $1 \mu \mathrm{g} / \mathrm{ml}$ with the blocking buffer. Then, they were incubated for $1 \mathrm{~h}$ with goat anti-mouse IgG and IgM peroxidase conjugate (Capel Research Products) diluted 1 in 500 with Trisbuffered saline containing bovine serum albumin (BSA) $1 \% \mathrm{w} / \mathrm{v}$. Immunoblots were developed with Tris-saline containing $\mathrm{H}_{2} \mathrm{O}_{2} \quad 0.12 \% \mathrm{v} / \mathrm{v}$ and $1 \mathrm{mM} \mathrm{o-}$ dianisidine.

\section{Immunohistochemical staining of gastric biopsy specimens with MAb H9 or MAb H2O to bacterial HSP60}

Frozen sections $4 \mu \mathrm{m}$ thickness obtained from six separate biopsy specimens were placed on glass slides. They were fixed in acetone for $5 \mathrm{~min}$ at $4^{\circ} \mathrm{C}$, followed by washing with distilled water. Endogenous peroxidase was blocked by incubation with $\mathrm{H}_{2} \mathrm{O}_{2} 0.1 \% \mathrm{v} / \mathrm{v}$ for $10 \mathrm{~min}$ at room temperature. After washing with PBS containing Tween 20 (Wako Pure Chemical Ltd) $0.2 \% \mathrm{v} / \mathrm{v}$ (washing buffer), the sections were allowed to react with normal horse serum diluted 1 in 10 with PBS-S for $30 \mathrm{~min}$ to reduce non-specific staining. The sections were then treated overnight at $4^{\circ} \mathrm{C}$ with either $\mathrm{MAb} \mathrm{H} 9$ or MAb H20 $(1 \mu \mathrm{g} / \mathrm{ml})$ diluted with PBS-S or control mouse MAb (IgG or $\mathrm{M}$ ) recognising glucose oxidase derived from Aspergillus niger (Dako Japan Co. Ltd, Kyoto, Japan). After the sections were treated with the washing buffer they were incubated with biotinylated anti-mouse $\mathrm{IgG}$ or IgM secondary antibody (Dako Japan Co. Ltd) diluted 1 in 100 with PBS-S. Development by the peroxidase method with avidinbiotinylated enzyme complex and 3,3'-diaminobenzidine, tetrahydrochloride was performed with the vectastain $\mathrm{ABC}$ kit (Funakoshi Co. Ltd, Tokyo, Japan).

\section{Results}

Cross-reaction between the affinity-purified antigens and MAb H9 or MAb H2O

The study determined whether the molecule recognised by $\mathrm{MAb} \mathrm{H} 9$ corresponded to that directed to MAb $\mathrm{H} 20$. The molecules recognised with the MAbs were purified by affinity chromatography with MAb H9 or MAb H20. The purified antigens cross-reacted with MAbs H9 and H20 (Fig. $1 \mathrm{a}$ and b). The purified antigen also reacted with $\mathrm{MAb} 3 \mathrm{C} 8$ raised against $Y$. enterocolitica HSP60 as previously established (Fig. 1c) [25 30]. The N-terminal amino-acid sequences of the $60-\mathrm{kDa}$ proteins recognised by both MAbs were as follows: ${ }^{* * * *}$ IKFSVYAMKLLFEGV ( ${ }^{*}$ denotes unsuccessful determination, and the underlined sequence shows an identical correspondence to $H$. pylori HSP60 reported previously $[31,32]$. These results indicate that the molecule recognised by both MAbs is a homologue of $H$. pylori HSP60.

\section{Reactivities of various bacteria and MKN45 cells} with MAbs H9 and H2O

Table 1 shows the reactivities of MAbs $\mathrm{H} 9$ and $\mathrm{H} 20$, in both ELISA and by immunoblotting against sonicated crude antigens of nine strains of $H$. pylori and seven other bacterial species including $H$. mustelae, $P$. aeruginosa, $S$. marcescens, Pr. mirabilis, $E$. coli and $S$. sonnei. MAb $\mathrm{H} 9$ displayed broad reactivity in ELISA, recognising all the bacterial antigens used in the present study. On the other hand, $\mathrm{MAb} \mathrm{H} 20$ recognised only the antigen from strains of $H$. pylori, indicating that this MAb reacted with a species-specific epitope. Similarly, it was demonstrated in immunoblotting that MAb H9 reacted with $60-\mathrm{kDa}$ antigens of all bacteria and MAb H2O recognised only the $60-\mathrm{kDa}$ antigen of strains of $H$. pylori. Both MAbs reacted with the $60-\mathrm{kDA}$ band in sonicated cell antigens of MKN45 by immunoblot analysis (Fig. 2).

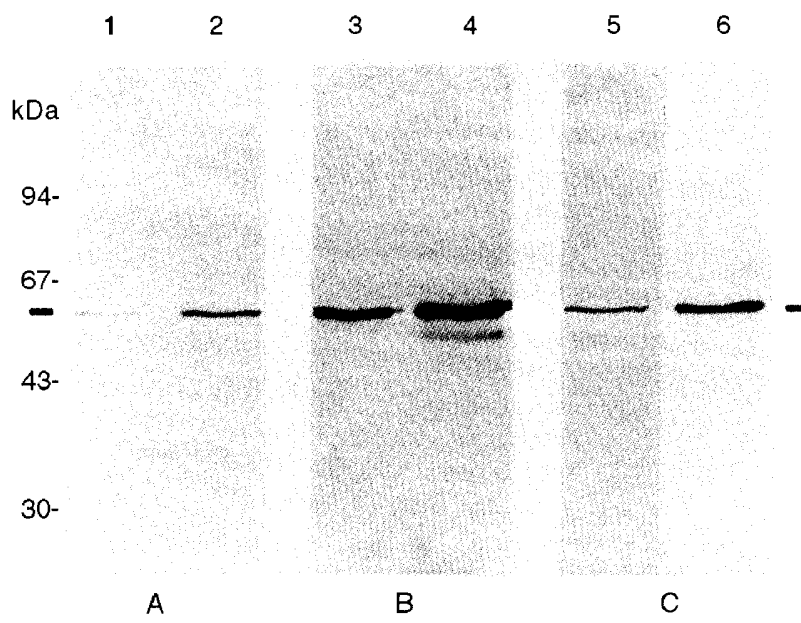

Fig. 1. Cross-reactivities of $60-\mathrm{kDa}$ antigen purified by affinity chromatography with MAb $\mathrm{H} 9$ or MAb H20 with (A) $\mathrm{H} 9$, (B) $\mathrm{H} 20$, MAB $3 \mathrm{C} 8$ (C). Lanes 1,3 and 5 were loaded with the antigen of $H$. pylori TK 1029 affinitypurified by MAb H9; lanes 2, 4, and 6 were loaded with the antigen affinity-purified by MAb H20. Bar: 60-kDa protein, reacting with MAbs $\mathrm{H} 9, \mathrm{H} 20$ and $3 \mathrm{C} 8$. 
Table 1. Reactivities* of bacterial extracts in ELISA and immunoblotting with MAbs directed against HSP60 of H. pylori TK 1029

\begin{tabular}{lccccc}
\hline & \multicolumn{2}{c}{ MAb H9 } & & \multicolumn{2}{c}{ MAb H20 } \\
\cline { 2 - 3 } \cline { 5 - 6 } Bacterial extract & ELISA Immunoblot & & ELISA Immunoblot \\
\hline H. pylori & & & & \\
TK1029 & $2.459^{\dagger}$ & + & 2.203 & + \\
TK1028 & 1.437 & + & 1.869 & + \\
TK1054 & 2.761 & + & 1.978 & + \\
TK1079 & 1.076 & + & 1.317 & + \\
TK1307 & 2.179 & + & 2.297 & + \\
ATCC43526 & 1.812 & + & 1.642 & + \\
ATCC43579 & 2.040 & + & 2.516 & + \\
ATCC43629 & 2.509 & + & 2.208 & + \\
ATCC49503 & 2.739 & + & 2.663 & + \\
H. mustelae & 1.235 & + & 0.029 & - \\
P. aeruginosa & 0.438 & + & 0.035 & - \\
V. cholerae & 0.586 & + & 0.032 & - \\
S. marcescens & 0.898 & + & 0.030 & - \\
Pr. mirabilis & 0.484 & + & 0.041 & - \\
E. coli & 0.528 & + & 0.030 & - \\
Sh. sonnei & 0.610 & + & 0.028 & - \\
\hline
\end{tabular}

+ , detection of reacting protein band of $60-\mathrm{kDa}$ by immunoblotting; --, denotes no detection of reacting band in the size by immunoblotting.

${ }^{*}$ Reactivities were measured by ELISA and immunoblot analysis.

${ }^{\dagger}$ Value of $\mathrm{OD}_{490}$ measured by ELISA.

Reactivities of gastric biopsy specimens with MAbs $\mathrm{H} 9$ and $\mathrm{H} 20$ by immunohistochemical staining

Immunohistochemical staining of six gastric biopsy specimens from patients with gastritis was performed with MAbs $\mathrm{H} 9$ and $\mathrm{H} 20$ directed against $H$. pylori HSP60 (Fig. 3). All gastric biopsy samples were positive for both the rapid urease test and the isolation of H. pylori. Gastric epithelial cells of four biopsy samples stained positively with MAb H20 (Fig. 3A, C, $\mathrm{D}$ and $\mathrm{F}$ ) but the other two biopsy specimens were not stained with MAb H20 (Fig. 3B and E). On the other hand, no gastric biopsy specimens reacted with either MAb H9 or negative control MAbs (both immunoglobulin $\mathrm{G}$ and $\mathrm{M}$ ) directed against the glucose oxidase derived from Aspergillus niger (data not shown).

\section{Discussion}

The present study established two MAbs, designated as $\mathrm{H} 9$ and $\mathrm{H} 20$, against $H$. pylori HSP60 and described the characteristics of the epitopes recognised by these MAbs. The epitope recognised by MAb H9 is similar to the common epitope recognised by $\mathrm{MAb} 3 \mathrm{C} 8$ as reported previously $[25,30]$, as MAb H9 reacted with the $60-\mathrm{kDa}$ protein of all bacteria used in the present study and MKN45 cells. In contrast, MAb H20 recognised the species-specific epitope on $H$. pylori HSP60 and the epitope was also shown to exist on a 60-kDa molecule of human gastric carcinoma MKN45 cells. It has already been reported that MAb H2O inhibited adhesion of $H$. pylori to human gastric

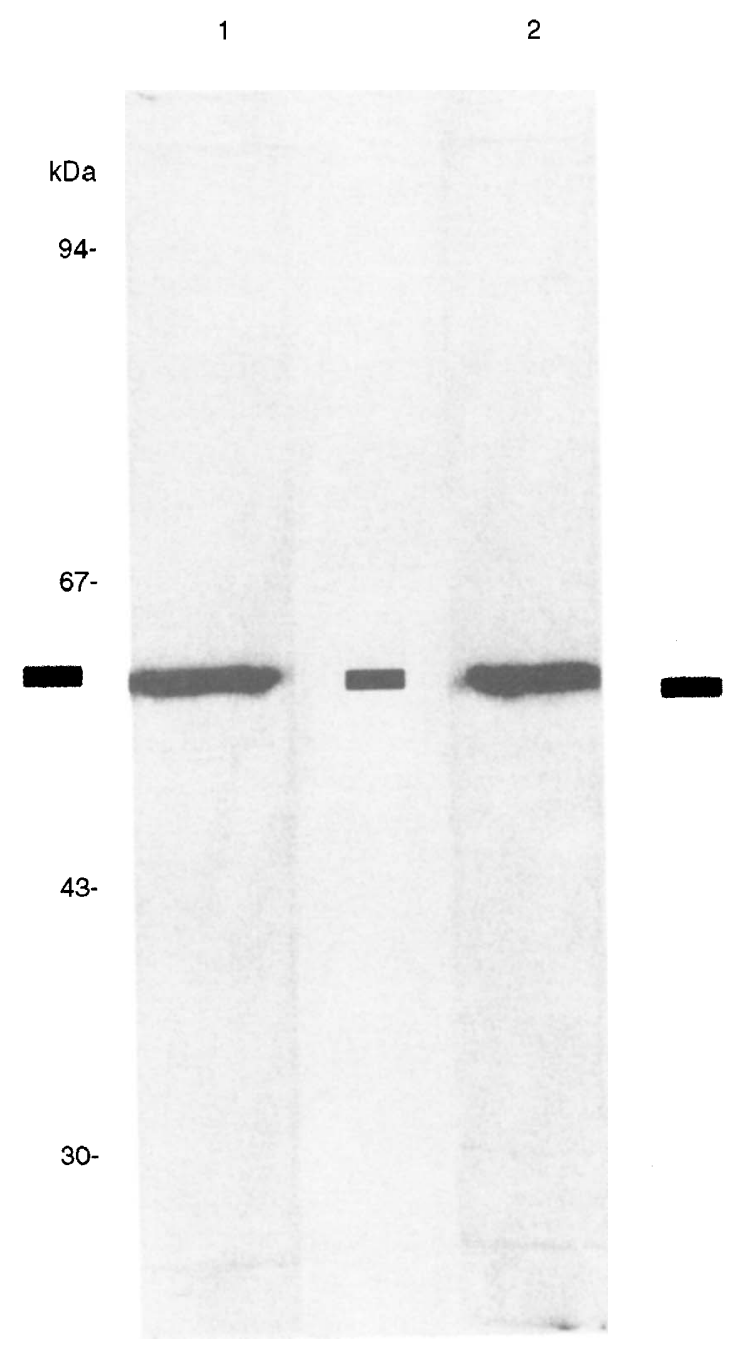

Fig. 2. Immunoblot analysis of human gastric carcinoma MKN45 cell with MAb H9 (lane 1) and MAb H20 (2); MKN45 cell lysates were loaded onto lanes 1 and 2. Bar: $60-\mathrm{kDa}$ protein, reacting with MAbs $\mathrm{H} 9$ and $\mathrm{H} 20$.

epithelial cells, indicating that the HSP60 epitope recognised by MAb H20 might be important in the adhesion of $H$. pylori [32]. The results indicated that a species-specific epitope exists on $H$. pylori HSP60 and there was epitope homology between $H$. pylori HSP60 and human gastric cells.

Immunohistochemical staining demonstrated that $\mathrm{MAb}$ H20 reacted with four of six gastric biopsy specimens obtained from patients with gastritis. In contrast, $\mathrm{MAb}$ $\mathrm{H} 9$ reacted with no gastric biopsy specimens at all. However, both MAbs reacted with the $60-\mathrm{kDa}$ molecule of human gastric carcinoma MKN45 cells in immunoblotting. These results indicated that the epitope recognised with $\mathrm{MAb} \mathrm{H} 20$ was $H$. pylorispecific and expressed on gastric epithelial cells as well as H. pylori, and that the amount of the expressed epitope differed among different gastric biopsy specimens. It also indicated that $\mathrm{MAb} \mathrm{H} 9$ reacting epitope is universally detected on a broad 


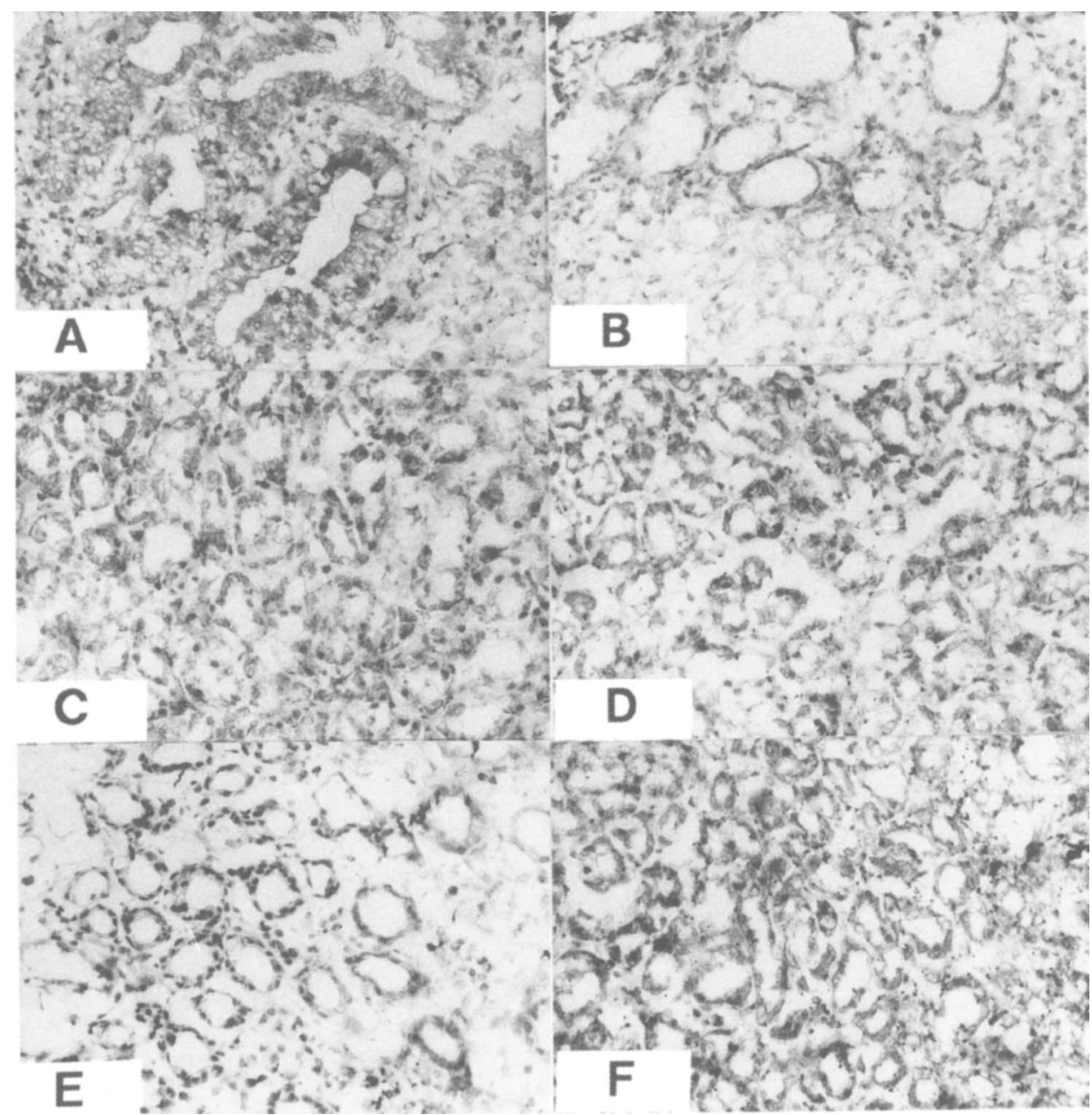

Fig. 3. Immunohistochemical staining of gastric biopsy specimens with MAb H20. Six gastric biopsy specimens (A-F) positive for both rapid urease test and isolation of $H$. pylori were stained with MAb H20. Magnification $\times 200$.

spectrum of bacteria but was not detected on primary gastric epithelial cells.

An autoimmune reaction in gastroduodenal diseases might play an important role in the pathogenicity of $H$. pylori [23, 33]. However, the $H$. pylori antigens that induce an autoimmune reaction are currently unknown. Appelmelk et al. [34] reported a potential role of molecular mimicry between $H$. pylori lipopolysaccharide and host Lewis blood group antigens in autoimmunity. Macchia et al. [31] suggested that a role for $H$. pylori HSP60 in induction of gastritis by autoimmunity might be important.

The role of HSPs in the pathogenesis of various diseases has been suggested in various clinical syndromes and bacterial infections [14, 35-37]. It was also reported that $H$. pylori induces an immune response against its $\mathrm{HSP} 60$ in $c .50 \%$ of patients infected by the bacterium and that sera from uninfected people do not recognise this protein [31]. The present study demonstrated an epitope homology between $H$. pylori HSP60 and human gastric epithelial cells. The results suggest that the recognition of its HSP60 in infection with $H$. pylori could induce an autoimmune reaction against gastric epithelial cells. HSP60 proteins are the most conserved proteins among all living organisms, not only in prokaryotic but also in eukaryotic cells $[17,18]$. The homology between the amino-acid sequences of these molecules is very high, indicating that a common epitope exists on HSP60. However, an intense immune response against the common epitope of $H$. pylori might not be important for the induction of autoimmunity, as such an immune response should be eliminated by tolerance [31].

Therefore, we speculate that the specific epitope on $H$. pylori HSP60, like the epitope recognised with MAb $\mathrm{H} 20$, and capable of cross-reacting with human gastric cells, could induce an autoimmune response against human gastric epithelial cells.

This study was supported in part by a grant for scientific research from the Ministry of Education, Science, Sport and Culture of Japan. 


\section{References}

1. Blaser MJ. Hypotheses on the pathogenesis and natural history of Helicobacter pylori-induced inflammation. Gastroenterology 1992; 102: 720-727.

2. Parsonnet J, Friedman GD, Vandersteen DP et al. Helicobacter pylori infection and the risk of gastric carcinoma. $N$ Engl $J$ Med 1991; 325: 1127-1131.

3. Parsonnet J, Hansen S, Rodriguez L et al. Helicobacter pylor infection and gastric lymphoma. $N$ Engl $J$ Med 1994; 330: $1267-1271$

4. Eaton KA, Morgan DR, Krakowka S. Campylobacter pylori virulence factors in gnotobiotic piglets. Infect Immun 1989; 57: $1119-1125$

5. O'Toole PW, Kostrzynska M, Trust TJ. Non-motile mutants of Helicobacter pylori and Helicobacter mustelae defective in flagellar hook production. Mol Microbiol 1994; 14: 691-703.

6. Evans DG, Evans DJ, Moulds JJ, Graham DY. N-acetylneuraminyllactose-binding fibrillar hemagglutinin of Campylobacter pylori: a putative colonization factor antigen. Infect Immun 1988; 56: 2896-2906.

7. Eaton KA, Krakowka S. Effect of gastric $\mathrm{pH}$ on ureasedependent colonization of gnotobiotic piglets by Helicobacter pylori. Infect Immun 1994; 62: 3604-3607.

8. Segal ED, Shon J, Tompkins LS. Characterization of Helico bacter pylori urease mutants. Infect Immun 1992; 60: $1883-$ 1889

9. Leunk RD, Johnson PT, David BC, Kraft WG, Morgan DR. Cytotoxic activity in broth-culture filtrates of Campylobacter pylori. J Med Microbiol 1988; 26: 93-99.

10. Kamiya S, Kai M, Ozawa A et al. Characteristics of vacuolating toxin produced by Helicobacter pylori. Eur $J$ Gastroenterol Hepatol 1994; 6: Suppl 1: S23-S27.

11. Cave DR, Vargas M. Effect of a Campylobacter pylori protein on acid secretion by parietal cells. Lancet 1989; 2: 187-189.

12. Peterson WL. Helicobacter pylori and peptic ulcer disease. $N$ Engl J Med 1991; 324: 1043--1048.

13. Born W, Hall L, Dallas A et al. Recognition of a peptide antigen by heat shock-reactive $\gamma \delta \mathrm{T}$ lymphocytes. Science 1990; 249: 67-69.

14. Kaufman SHE, Schoel B, Wand-Wurttenburger A, Steinhoff U, Munk ME, Koga T. T-cells, stress proteins, and pathogenesis of mycobacterial infections. Curr Top Microbiol Immunol 1990; 155: $125-141$.

15. Young DB. Chaperonins and the immune response. Semin Cell Biol 1990; 1: 27-35

16. Creighton TE. Unfolding protein folding. Nature 1991; 352 $17-18$.

17. Ellis RJ. The molecular chaperone concept. Semin Cell Biol $1990 ; 1: 1-9$.

18. Hemmingsen SM, Woolford C, van der Vies SM et al. Homologous plant and bacterial proteins chaperone protein assembly. Nature 1988; 333: 330-334.

19. Doyle EJ, Evans DG, Engstrand L, Graham DY. Ureaseassociated heat shock protein of Helicobacter pylori. Infect Immun 1992; 60: 2125-2127.

20. Guillermo IPP, Perez Perez GI, Olivares AZ, Cover TL, Blaser MJ. Characteristics of Helicobacter pylori variants selected for urease deficiency. Infect Immun 1992; 60: 3658-3663.

21. Yamaguchi $H$, Osaki $T$, Taguchi $H$, Hanawa T, Yamamoto $T$, Kamiya S. Flow cytometric analysis of the heat shock protein
60 expressed on the cell surface of Helicobacter pylori. $J \mathrm{Med}$ Microbiol 1996; 45: 270--277.

22. Negrini R, Lisato L, Zanella I et al. Helicobacter pylori infection induces antibodies cross-reacting with human gastric mucosa. Gastroenterology 1991; 101: 437-445.

23. Negrini R, Savio A, Graffeo M, Rolfi F, Ghielmi S Autoantibodies and gastric Helicobacter pvlori infection: does autoimmunity affect progression to atrophic gastritis? Eur $J$ Gastroenterol Hepatol 1993; 5 Suppl 2: S27-S29.

24. Kamiya S, Taniguchi I, Yamamoto $\mathrm{T}$ et al. Evaluation of rapid urease test for detection of Helicobacter pylori in gastric biopsy specimens. Eur J Epidemiol 1993; 9: 450-452.

25. Yamaguchi $\mathrm{H}$, Yamamoto $\mathrm{T}$, Taguchi $\mathrm{H}$, Ogata $\mathrm{S}$. Yersinia enterocolitica immunodominant $60 \mathrm{kDa}$ antigen, common to a broad range of bacteria, is a heat-shock protein. $J$ Gen Microbiol 1990; 136: 1091-1097.

26. Yamaguchi H, Taguchi H, Katura T, Kumada J, Uekusa T, Ogata $\mathrm{S}$. Purification of cross-reacting protein antigen shared by Yersinia enterocolitica and other gram-negative bacteria with monoclonal antibody. Microbiol Immunol 1989; 33: 683-688.

27. Yamaguchi $\mathrm{H}$, Miura $\mathrm{H}$, Ohsumi $\mathrm{K}$ et al. Detection and characterization of antibodies to bacterial heat-shock protein 60 in sera of patients with primary biliary cirrhosis. Microbiol Immunol 1994; 38: 483-487.

28. Laemmli UK. Cleavage of structural proteins during the assembly of the head of bacteriophage T4. Nature 1970; 227: $680-685$.

29. Towbin H, Staehelin T, Gordon J. Electrophoretic transfer of proteins from polyacrylamide gels to nitrocellulose sheets: procedure and some applications. Proc Natl Acad Sci USA 1979; 76: 4350-4354.

30. Yamaguchi H, Yamamoto T, Konoeda Y, Taguchi H, Ogata S. Epitope homology between bacterial heat shock protein and self-proteins in the host cell. APMIS 1992; 100: 957-962.

31. Macchia G, Massone A, Burroni D, Covacci A, Censini S, Rappuoli R. The Hsp60 protein of Helicobacter pylori: structure and immune response in patients with gastroduodenal diseases. Mol Microbiol 1993; 9: 645-652.

32. Yamaguchi $\mathrm{H}$, Osaki $\mathrm{T}$, Kurihara $\mathrm{N}$ et al. Heat-shock protein 60 homologue of Helicobacter pylori is associated with adhesion of $H$. pylori to human gastric epithelial cell. $J \mathrm{Med}$ Microbiol 1997; 00: 000-000.

33. Vollmers HP, Dammrich J, Ribbert $\mathrm{H}$ et al. Human monoclonal antibodies from stomach carcinoma patients react with Helicobacter pylori and stimulate stomach cancer cells in vitro. Cancer 1994; 74: 1525-1532.

34. Appelmelk BJ, Simoons-Smit I, Negrini R et al. Potential role of molecular mimicry between Helicobacter pylori lipopolysaccharide and host Lewis blood group antigens in autoimmunity. Infect Immun 1996; 64: 2031-2040.

35. Lehner T, Lavery E, Smith R, van der Zee R, Mizushima $Y$, Shinnick T. Association between the 65-kilodalton heat shock protein, Streptococcus sanguis, and the corresponding antibodies in Behcet's syndrome. Infect Immun 1991; 59: 1434 1441.

36. Yi Y, Zhong G, Brunham RC. Continuous B-cell epitopes in Chlamydia trachomatis heat shock protein 60 . Infect Immum 1993; 61: $1117-1120$

37. $\mathrm{Xu} \mathrm{Q}$, Willeit J, Marosi $\mathrm{M}$ et al. Association of serum antibodies to heat-shock protein 65 with carotid atherosclerosis. Lancet 1993; 341: 255-259. 